\title{
A diverse assemblage of Permian echinoids (Echinodermata, Echinoidea) and implications for character evolution in early crown group echinoids
}

\author{
Jeffrey R. Thompson, Elizabeth Petsios, and David J. Bottjer \\ Department of Earth Sciences, Zumberge Hall of Science, University of Southern California, 3651 Trousdale Parkway, Los Angeles, California \\ 90090-0740, USA 〈thompsjr@usc.edu〉, 〈petsios@usc.edu〉, 〈dbottjer@usc.edu〉
}

\begin{abstract}
The Permian is regarded as one of the most crucial intervals during echinoid evolution because crown group echinoids are first widely known from the Permian. New faunas provide important information regarding the diversity of echinoids during this significant interval as well as the morphological characterization of the earliest crown group and latest stem group echinoids. A new fauna from the Capitanian Lamar Member of the Bell Canyon Formation in the Guadalupe Mountains of West Texas comprises at least three new taxa, including Eotiaris guadalupensis Thompson n. sp. an indeterminate archaeocidarid, and Pronechinus? sp. All specimens represented are silicified and known from disarticulated or semiarticulated interambulacral and ambulacral plates and spines. This assemblage is one of the most diverse echinoid assemblages known from the Permian and, as such, informs the paleoecological setting in which the earliest crown group echinoids lived. This new fauna indicates that crown group echinoids occupied the same environments as stem group echinoids of the Archaeocidaridae and Proterocidaridae. Furthermore, the echinoids described herein begin to elucidate the order of character transitions that likely took place between stem group and crown group echinoids. At least one of the morphological innovations once thought to be characteristic of early crown group echinoids, crenulate tubercles, was in fact widespread in a number of stem group taxa from the Permian as well. Crenulate tubercles are reported from two taxa, and putative cidaroid style U-shaped teeth are present in the fauna. The presence of crenulate tubercles in the archaeocidarid indicates that crenulate tubercles were present in stem group echinoids, and thus the evolution of this character likely preceded the evolution of many of the synapomorphies that define the echinoid crown group.
\end{abstract}

\section{Introduction}

Echinoids are members of the phylum Echinodermata and are important and common constituents of modern ecosystems (e.g., Kier and Grant, 1965; de Beer, 1990; Gagnon and Gilkinson, 1994; Nebelsick, 1996; Linse et al., 2008). Although they encompass a wide morphological diversity in the postPaleozoic (Hopkins and Smith, 2015), echinoids are first known from the Ordovician (Smith and Savill, 2001; Reich and Smith, 2009) and following a maximum Paleozoic generic richness in the Carboniferous (Kier, 1965; Smith, 1984) underwent a severe bottleneck at the Permo-Triassic mass extinction (Erwin, 1993, 1994; Twitchett and Oji, 2005). Apart from disarticulated spines, echinoids in Paleozoic strata are relatively rare. Prior to the Permian, most echinoids had flexible tests, with many clades displaying imbricate plating presumably lacking the stereomic interlocking present in post-Paleozoic clades (Smith, 1980a). Because of this nonrigid test plating, Paleozoic echinoids disarticulated rapidly following their death, and thus articulated echinoid material from the Paleozoic is often limited to Lagerstätte (e.g., Schneider et al., 2005). Given their propensity to disarticulate (e.g., Thompson and Ausich, 2016; Thompson and Denayer, 2016), echinoid diversity in the Paleozoic is almost certainly underestimated, and thus all new taxa are important. Furthermore, the late Paleozoic has been demonstrated to be the interval in which the first crown group echinoids are known from the fossil record (Smith et al., 2006; Nowak et al., 2013; Thompson et al., 2015b). As such, new faunas are important as they allow for a greater understanding of the morphological innovations present in these earliest crown group and latest stem group echinoids and the environments and communities in which the evolution of the first crown group echinoids took place.

Examination of material in the collections of the National Museum of Natural History in Washington D.C. revealed new specimens representing several taxa of at least three families, the Miocidaridae, Archaeocidaridae, and Proterocidaridae, from the Guadalupian Bell Canyon Formation of West Texas. The fauna herein described is the first well-preserved assemblage of Permian echinoids comprising taxa of multiple families and represents one of the most diverse assemblages of echinoids known thus far from the Permian. The assemblage contains the first known occurrence of the Proterocidaridae in the Permian of North America and increases the number of stem cidaroid taxa known from the Permian to three. The discovery of this fauna also indicates that echinoids were likely more geographically widespread in the Permian than previously thought. Among these new specimens is the recently described, and herein validated, Eotiaris guadalupensis Thompson n. sp. representing the earliest known cidaroid and crown group echinoid known in the 
fossil record (Thompson et al., 2015b). Furthermore, the echinoids described herein demonstrate that some of the morphological innovations associated with the echinoid crown group were in fact present in numerous stem group taxa in the Permian.

\section{Geologic setting}

All specimens were collected from the Lamar Member of the Bell Canyon Formation from the Guadalupe Mountains of West Texas. From 1939 to 1968, numerous expeditions were made by G. A. Cooper and others to the Permian outcrops of West Texas. The specimens herein described were collected during those excursions. In the Guadalupe Mountains, a number of microfossil taxa have yielded good biostratigraphic control. From the concurrent presence of the conodonts Jinogondolella postserrata (Behnken, 1975) and J. shannoni Wardlaw in Wardlaw and Mei, 1998, the Lamar Member of the Bell Canyon Formation has been determined to be Capitanian in age (Lambert et al., 2002; Lambert, 2006). The transition from the $J$. postserrata Zone to the $J$. shannoni Zone takes place within the uppermost Lamar Limestone Member (Lambert et al., 2010), thus indicating a lower Capitanian age (ca. $264 \mathrm{ma}$ ) (Henderson et al., 2012). The uppermost Lamar Limestone Member also marks the transition from J. shannoni to J. altudaensis (Kozur, 1992). The presence of both of these faunal transitions allows for relatively precise biostratigraphic control and clarifies the age of the Lamar Limestone Member to lower Capitanian (263-264 Ma).

The Lamar Member of the Bell Canyon Formation was deposited in the Delaware Basin and is spatially located to the southeast of the Guadalupe Mountains and the Capitan Formation. The Lamar Member contains carbonate debris flows transported from the reef edge sediments of the Capitan Formation. The unit displays a wedge-shaped morphology, being over $90 \mathrm{~m}$ thick near the shelf margin, where allochthonous sedimentation from the reefal sediments represented by the Capitan Formation was greatest, and thinning basinward to only about $2 \mathrm{~m}$ (Babcock, 1977). The Capitan Formation and the Bell Canyon Formation are coeval (Lambert et al., 2010), and merge toward the edge of the Delaware Basin. Close to the basin edge, at the type section of the Reef Trail Member (which overlies the Lamar Limestone Member), the Lamar Limestone Member was described as containing medium to dark gray organic-rich mudstones, and skeletal, peloidal wackestones and packstones with interspersed carbonate debris flows containing silicified fossils (Lambert et al., 2010). Babcock (1977) noted the presence of numerous transported silicified reef fossils infilling channels in the zone proximal to the reef. Proximal to the reef edge, the fauna of the Lamar Limestone Member consists of brachiopods, bryozoans, and crinoids (Babcock, 1977). Cooper and Grant (1972) furthermore noted that the brachiopod fauna in the Lamar was similar to that occurring on the 'reef slope.' Of special importance to this paper, silicified echinoid spines and plates have been noted as common in these debris flows (Babcock, 1977, p. 365, fig. 5). Basinward, the Lamar Limestone Member thins and is composed primarily of finely laminated mud lacking fossils and bioturbation (Babcock, 1977). The specimens discussed in this study were collected from localities USNM 725e, 728p, and 738b near the Guadalupe
Mountains (Cooper and Grant, 1972), which are interpreted as having been deposited near a shelf margin.

\section{Materials and methods}

Following their collection, specimens were prepared out of bulk limestone blocks at the USNM by using the hydrochloric acid dissolution method of Cooper and Grant (1972). Observations were made using dissecting microscopes, and specimens were measured using calipers. Silicified fossils are common in the Lamar Limestone (Cooper and Grant, 1972; Babcock, 1977), and all Lamar echinoid specimens discussed in this study are silicified. Fine scale details of plate structure and tuberculation are obscured by silicification, and stereomic microstructure is lacking from the surface of specimens. Cooper and Grant (1972) discussed two types of silicification present among the fossils of the Glass Mountains. One of these preservation types results in a thin coat of silica on the surface of the specimens, which, when treated with acid, protects the calcite on the interior of the plate from disintegration. This is the nonpervasive silicification discussed by Butts and Briggs (2011), and indeed, some echinoid specimens within this fauna are preserved with only a thin layer of silica and thus contain calcitic interiors. The second type of silicification mentioned by Cooper and Grant (1972) is complete replacement, where the entire fossil has been recrystallized to silica. This is also common among the specimens described herein.

Repositories and institutional abbreviations.-Institutional abbreviations for specimen repositories are as follows: USNM = United States National Museum, Washington D. C., USA; MGL = Musée d'Histoire Naturelle de Lille, France; NMS $\mathrm{G}=$ National Museum of Scotland, Edinburgh, Scotland; RGM = Naturalis Biodiversity Center, Leiden, The Netherlands.

\section{Systematic paleontology}

Terminology and classification follows Smith (1984) and Kroh and Smith (2010). Methodology follows Lewis and Donovan (2007).

\author{
Class Echinoidea Leske, 1778 \\ Subclass Cidaroidea Smith, 1984 \\ Family Miocidaridae Durham and Melville, 1957
}

Type genus.—Miocidaris Döderlein, 1887

Other genera.-Eotiaris Lambert, 1899, Couvelardicidaris Vadet, 1991, Procidaris Pomel, 1883

\section{Genus Eotiaris Lambert, 1899}

Type species.-Cidaris keyserlingi Geinitz, 1848, from the Wuchiapingian Zechstein of Germany and England.

Diagnosis.-Miocidarid with small test. Interambulacral plates imbricate adapically. Aureoles confluent only at and below ambitus. Spines with spinules. 
Occurrence.-Wuchiapingian of Germany, the United Kingdom, and Roadian and Guadalupian of Texas.

Eotiaris guadalupensis Thompson new species urn:1sid:zoobank.org:act:6B7A2509-8B8D-4A48-9C186BAF42BB9E51

Figure 1.1-1.5

1958b Spine Kier, p. 889, pl. 114, fig. 3. v. 1965 Miocidaris sp.; Kier, p. 456.

v. 2015a Eotiaris guadalupensis; Thompson et al., p. 3, fig. 1. Unavailable name.

Holotype.-The holotype is specimen USNM 610600 (Fig. 1.5).

Diagnosis.—Eotiaris with straight, clavate and bulbous spines covered in numerous spinules arranged helically around the shaft.

Occurrence.-The specimens discussed and figured herein are known from the Lamar Member of the Bell Canyon Formation of the Guadalupe Mountains. They are thus Capitanian in age.

Localities are USNM 725e, 728p, and 738b from Cooper and Grant (1972) with coordinates from Wardlaw (2008). USNM 725e has latitude and longitude coordinates in decimal degrees of $31.9474,104.7075$. Type locality USNM $728 p$ is located at $31.942,104.701$ and locality USNM $738 \mathrm{~b}$ is at 31.981, 104.7497. Specimens of E. guadalupensis are also known from the Road Canyon and Word formations of the Glass Mountains of West Texas. The road Canyon Formation is, at the youngest, Roadian, while the Word Formation is Wordian.

Description.-See Thompson et al. (2015b) p. 3-4 for description of this taxon.

Etymology._-guadalupensis from the Guadalupe Mountains of west Texas, from where the type material was collected.

Materials.-USNM 610600 (Fig. 1.5), which is the holotype and USNM 610601 (Fig. 1.4)-610605, which are paratypes.

Remarks.-The description of this species was published in the online only journal Scientific Reports, and the name was not registered with ZooBank, making it unavailable. The name is herein validated. Because this species was very recently described (Thompson et al., 2015b), no further description is warranted here. We have figured, however, the proximal spine shaft, milled ring, and base of the spines of this taxon (Fig. 1.1-1.3), which appears to be diagnostic due to the distinct diagonally oriented ridge and furthermore allows for attribution of disarticulated spines to the coronas. In addition, two of the type specimens, the holotype (USNM 610600; Fig. 1.5) and one of the paratypes (USNM 610601; Fig. 1.4), have been figured for completeness of the fauna.

Stem Group Echinoidea

Family Archaeocidaridae M'Coy, 1844
Type genus.—Archaeocidaris M'Coy, 1844

Archaeocidaridae indet.

Figure 2.4-2.14

Occurrence.-Lamar Member of the Bell Canyon Formation of the Guadalupe Mountains, West Texas. Localities 728p, 725e, 738b from Cooper and Grant (1972). See preceding description of localities in Eotiaris guadalupensis for details.

Description.-This taxon is only known from disarticulated interambulacral plates and spines. Tubercles perforate and crenulate. Mamelons in the shape of an inverted cone. Crenulations present in between parapet edge and mamelon and appear as extensions of the parapet projecting radially inward toward the mamelon (Fig. 2.6, 2.7). Some plates show diagenetic alteration in the morphology of the mamelon, and as such, it is difficult to discern whether they are crenulate (Fig. 2.4, 2.8). Radial plications present faintly (Fig. 2.4). Interior of plates slightly concave (Fig. 2.5) with denticles present on adambulacral edges (Fig. 2.9). Hexagonal plates are also present, which lack denticles (Fig. 2.4, 2.5), indicating that the interambulacral plates were arranged into more than two columns per area. There are two distinct interambulacral plate morphotypes present in the assemblage, and whether they represent two distinct taxa or plate variability within a species or individuals is unknown. We have chosen to treat all disarticulated archaeocidarid ossicles together as one taxon until better material is known and there is justification for, or against, subdivision into different taxa. The first plate morphotype consists of plates ranging from width about 1.1 to 1.23 times height (Fig. 2.4, 2.5). Boss about 0.4 to 0.5 times as wide as plate and 0.5 to 0.6 times as high as plate. One ring of scrobicular tubercles present adjacent to plate edge with about 19 scrobicular tubercles per plate. Scrobicular tubercles on raised edge of plate such that area between tubercles is also raised relative to the aureole. Tubercles sunken relative to scrobicular ring. Median (interradial) interambulacral plates hexagonal, adambulacral (adradial) plates pentagonal with adambulacral scrobicular ring slightly thicker than rest of plate. The second morphotype consists of plates that are about equally high as wide to 1.2 times higher than wide (Fig. 2.6-2.9). Median interambulacral plates hexagonal, adambulacral plates pentagonal. Plates have one row of scrobicular tubercles on their lateral margins, but may have more than one on their adoral and adapical edges. These additional rows of scrobicular tubercles contain smaller tubercles. About 20-22 scrobicular tubercles per plate. The primary tubercles are less sunken than the tubercles in the first morphotype. Spines straight with alternating rows of spinules (Fig. 2.10, 2.13, 2.14). In cross section, spines appear to be triangular to circular and appear to be hollow (Fig. 2.11, 2.12), though it is difficult to tell whether this is a true morphological feature or taphonomic.

Materials.-Over 100 disarticulated plates and spine fragments were examined. Specimen USNM 617187 is one lot of disarticulated spines of Archaeocidaridae indet. USNM 617188 is one lot of interambulacral plates belonging to the first plate morphology while USNM 617189 is one lot of disarticulated 


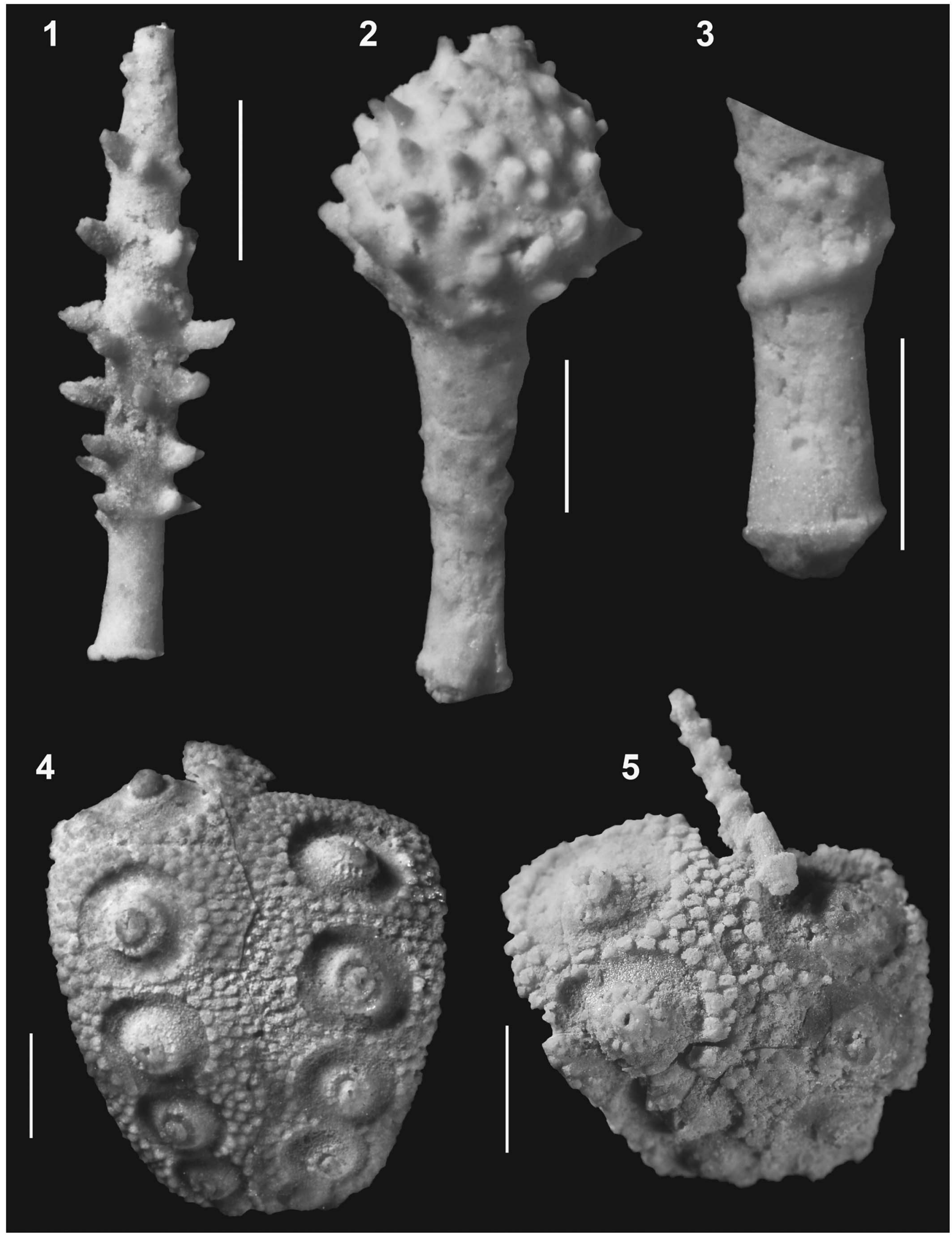


interambulacral plates belonging to the second plate morphotype.

Remarks.-Although very few species of Archaeocidaris based off of articulated or semiarticulated test material are known from the Permian, numerous plates and spines that have been attributed to Archaeocidaris are known globally (e.g., Waagen, 1885; Prosser, 1895; Kittl, 1904; Gortani, 1905; Boos, 1929; Wanner, 1941; Matthieu, 1949; Kier, 1958b; Leupke, 1976; Simpson, 1976; Mihály, 1980; Webster and Jell, 1992; Hlebzevitsch and Cortiñas, 2009; Schneider, 2010). As cautioned by Kier (1958a, 1965), because different genera within the Archaeocidaridae have differing numbers of interambulacral columns, it is best not to assign disarticulated archaeocidarid plates to a particular genus. That being the case, these plates likely belong to Archaeocidaris as the genus Polytaxicidaris Kier, 1958 a is not known from outside of the Mississippian, and the species of Polytaxicidaris for which external plate morphology is well known, Polytaxicidaris lirata Kier, 1965, displays perforate secondary tubercles (Kier, 1965, figs. 4, 6) and are very unlike the plates described herein. However, because this determination is not definitive, and because of its crenulate tubercles, the taxon is designated as Archaeocidaridae indet. The shape and secondary tuberculation of the first plate morphotype is similar to the interambulacral plate morphology of numerous Archaeocidaris species, including Archaeocidaris brownwoodensis Schneider, Sprinkle, and Ryder, 2005, Archaeocidaris marmorcataractensis Thompson et al., 2015a, and Archaeocidaris wortheni Hall, 1858. The shape of the second plate morphotype, with its extended flange adorally and aborally, is similar to that of the plates of Archaeocidaris rossica (von Buch, 1840) from the Pennsylvanian of Russia. This plate morphotype is also present in Archaeocidaris selwyni Etheridge, 1892 and archaeocidarids described as 'Cidaroid indet.' in Webster and Jell (1992) from the Permian of Australia, Archaeocidaris manhattanensis Matthieu, 1949 (Fig. 2.2) from the Permian of Kansas, and Archaeocidaris aculeata Shumard in Shumard and Swallow, 1858 from the Pennsylvanian of Kansas. The plates of the indeterminate archaeocidarid from the Bell Canyon Formation, however, are different from those of these aforementioned taxa in that they display crenulate tubercles (Fig. 2.6, 2.7). The only definitive species of Archaeocidaris with crenulate tubercles is Archaeocidaris apheles Schneider, Sprinkle, and Ryder, 2005; however, these are merely faint indentations on the platform of the tubercle, and may not be homologous with true crenulate tubercles. Archaeocidaris forbesiana (de Koninck, 1863), which was placed into Archaeocidaris tentatively by Jackson (1912), was illustrated with crenulate tubercles by Waagen (1885). In addition, crenulate tubercles are known from echinoids from the Permian of Timor (Wanner, 1941; Fig. 2.1). That crenulate tubercles are clearly present in the indeterminate archaeocidarid described herein indicates that the crenulate tubercles illustrated by Waagen (1885) were likely truly present on the figured specimens and that crenulate tubercles were likely widespread among numerous taxa in the Permian. Crenulate tubercles are also present in miocidarids such as Eotiaris keyserlingi (Geinitz, 1848) and Eotiaris guadalupensis, and the importance of crenulate tubercles on Archaeocidaris? sp. will be discussed further in the following.

It is also necessary herein to address the genus Permocidaris Lambert, 1900, which has been regarded within the Miocidaridae by Smith and Kroh (2011) and has also been described as having crenulate tubercles. The type species of Permocidaris is Cidaris forbesiana de Koninck, 1863, and the type specimen is NMS G.1871.1.34. The type of Cidaris forbesiana consists of several disarticulated spines that are clavate in morphology, bearing columns of spinules arranged laterally from the proximal end, slightly above the milled ring, to the distal end (Fig. 2.3). Waagen (1885) attributed several disarticulated interambulacral plates to this species, while transferring it to the genus Eocidaris Desor, 1856. He and Bather (1909) pointed out that these plates were not definitively associated with the spines described by de Koninck (1863). Bather (1909) rightly pointed out that, dependent upon the morphology of the interambulacral plates, there seems little to distinguish Permocidaris from Archaeocidaris save for its crenulate tubercles. However, because the material attributed by Waagen (1885) to Eocidaris forbesiana and the spines similar to the type of Eocidaris forbesiana have not been found in direct association, it is best to treat this material as indeterminate, and as such, we treat the genus Permocidaris Lambert, 1900 as incertae sedis. Furthermore, as this genus is known solely from disarticulated spines and plates, its familial level affiliation is uncertain. Smith and Kroh (2011) choose to place it within the Miocidaridae, one of the diagnosable characters of which is the presence of two columns of interambulacral plates. As the number of interambulacral columns of this taxon is unknown, however, this seems unadvisable. Furthermore, if the interambulacral plates assigned by Waagen (1885) to Eocidaris forbesiana are similar in nature to the interambulacral plates herein assigned to Archaeocidaridae indet., then they may well in fact have been arranged into more than two columns of interambulacral plates, as is the case with the latter. Permocidaris? timorensis Wanner, 1941 from the Permian of Timor also appears to have interambulacral plates bearing crenulate tubercles arranged into more than two columns, as plates both with and without a denticulate margin bear crenulations (Wanner, 1941, pl. 25, figs. 11-19). Because both of these taxa have more than two columns of interambulacral plates and crenulate primary tubercles, they may be closely aligned. Because of the incomplete nature of specimens of both taxa, however, we find it best to treat both as indeterminate.

Family Proterocidaridae Smith, 1984

Type genus._Proterocidaris de Koninck, 1882

Genus Pronechinus Kier, 1965

Type species.-Pronechinus anatoliensis Kier, 1965 from the Changhsingian of southeastern Turkey.

Figure 1. Cidaroid echinoids from the Bell Canyon Formation. (1) Straight spine of Eotiaris guadalupensis (USNM 610605c); (2) clavate spine of Eotiaris guadalupensis (USNM 610605a); (3) spine base and milled ring of USNM 610605 (same as 2.2); (4) paratype of Eotiaris guadalupensis (USNM 610601). This specimen consists of a single interambulacral area with at least six interambulacral plates in each column. (5) Holotype of Eotiaris guadalupensis (USNM 610600). Note crenulate tubercles and spine, which is morphologically similar to those in Figure $1.1-1.3$. Scale bars $=2.5 \mathrm{~mm}$. 


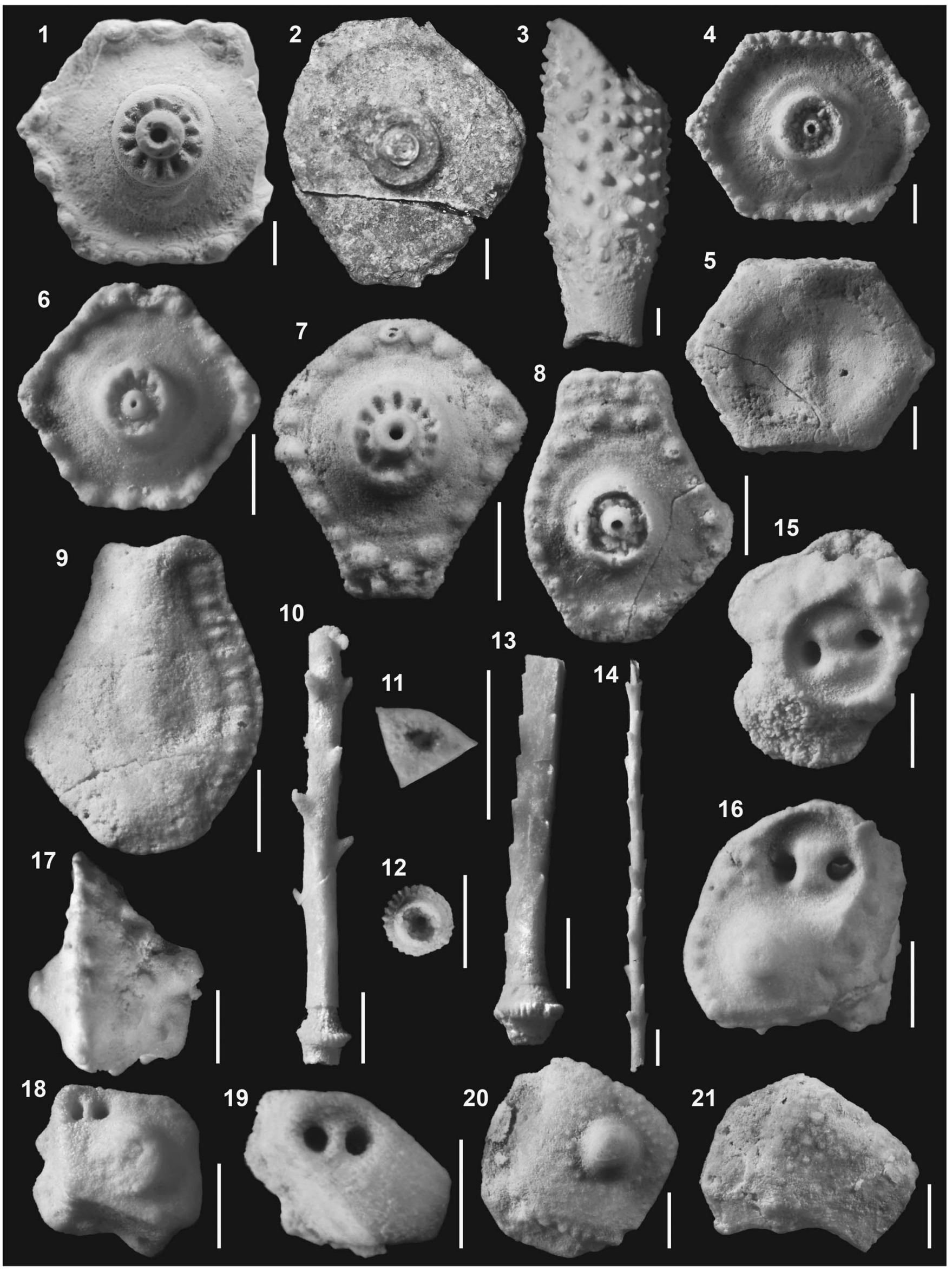


Other species.—Pronechinus cretensis König, 1982 from the Asselian of Crete.

Pronechinus? sp.

Figure 2.15-2.21

Occurrence.-Lamar Member of the Bell Canyon Formation of the Guadalupe Mountains, West Texas. Capitanian in age. Locality 728p from Cooper and Grant (1972). See preceding description of localities in Eotiaris guadalupensis for details.

Description.-This taxon is known only from disarticulated ambulacral and interambulacral plates. Ambulacral plates variably polygonal in shape. Some plates bear well-defined imperforate tubercles (Fig. 2.15) while others do not (Fig. 2.19). In addition, some pore pairs are surrounded by distinct peripodia (Fig. 2.15, 2.16). Peripodia about 0.5 to 0.8 times as wide as plates. Ambulacral plates both with and without primary tubercle can bear smaller secondary tubercles. Pore pairs perforating ambulacral plates at about halfway through their thickest point. Ambulacral plates with adoral margin heavily beveled, and ambulacral plating almost certainly imbricate. Interambulacral plates also imbricate, larger than ambulacral plates. All bearing minute tubercles but with some additionally bearing distinct imperforate primary tubercles.

Materials.-USNM 617192 and USNM 617193 (Fig. 2.15) are ambulacral plates with well-defined peripodial rims. USNM 617194 (Fig. 2.16) is an ambulacral plate with a well-defined peripodial rim and imperforate tubercle. USNM 617195 (Fig. 2.18) is an ambulacral plate without a well-defined peripodial rim and an imperforate tubercle. USNM 617196 (Fig. 2.19) lacks both a welldefined peripodial rim and a primary tubercle. USNM 617198617200 are lots of ambulacral plates and USNM 617197 and 617201 (Fig. 2.20, 2.21) are lots of interambulacral plates.

Remarks.-This taxon is questionably assigned to Pronechinus because the details of the arrangement of its test plating are incompletely known. The details of the interambulacral and ambulacral plates, however, confidently allow placement within the Proterocidaridae. Pronechinus is the only proterocidarid that has numerous ambulacral plates with small tubercles lacking peripodia yet containing large tubercles. These plates are located within the more perradial ambulacral columns of Pronechinus anatoliensis, and this tuberculate morphology is present among the ambulacral plates described herein (Fig. 2.18). Proterocidaris belli (Kier, 1965) from the Pennsylvanian Marble Falls Formation of
Texas has ambulacral plates with adoral tubercles; however, all of these plates bear peripodia (Kier, 1965). In addition, it is likely that the interambulacral plates with primary tubercles described herein are adambulacral in origin, as the adambulacral plates of Pronechinus anatoliensis bear distinct primary tubercles (Kier, 1965). Pronechinus is known from two species, Pronechinus cretensis and Pronechinus anatoliensis from the Asselian and Changhsingian respectively (Fig. 4). This is the first putative occurrence of this genus in the Capitanian and the first occurrence of a proterocidarid in the Permian of North America, indicating that the Proterocidaridae were likely biogeographically widespread in the Permian.

\section{Echinoidea indet. \\ Figure 3.1-3.3}

\section{Occurrence.-Same as for Eotiaris guadalupensis.}

Description.-Numerous disarticulated fragments of Aristotle's lanterns with associated teeth are present among the described fauna. Most of the fragments are disarticulated hemipyramids, though some articulated hemipyramids with teeth are present (Fig. 3.1-3.3). Maximum height of hemipyramid is $16.44 \mathrm{~mm}$. Foramen magnum is $1.58 \mathrm{~mm}$ deep on this specimen and generally sloping at about $50^{\circ}$ to the horizontal. Depth and angle of foramen magnum are variable; however, even in smaller specimens, the foramen magnum never appears to exceed 0.2 times the height of the hemipyramids. Protractor muscle scars about halfway down length of hemipyramid terminating in deep perforation. Retractor muscle attachment scars below. The wing edge is a faint ridge along the side of the hemipyramids, though may be faint due to preservational biases. Wings about 0.3 times as long as hemipyramids are high. Dental slide present. Teeth U-shaped, nonserrate.

Materials.-Lanterns are in lots USNM 617190 (Fig. 3) and 617191.

Remarks.-It is unknown whether the pyramids described here can be attributed to any of the taxa described herein. The hemipyramids are much taller than the test of Eotiaris guadalupensis; thus, it is unlikely that the pyramids belong to this taxon. Smith and Hollingworth (1990) described the lantern of Eotiaris keyserlingi, which is much smaller than the pyramids discussed here. The morphology of lanterns of echinoids in the upper Paleozoic is rarely described in detail (though see Lewis and Ensom [1982] for a counter example). The indeterminate pyramids described here appear to be similar in morphology to

Figure 2. Permian archaeocidarids from Timor, Kansas, the Salt Range (presumably Pakistan), and west Texas, and ambulacral and interambulacral plates of Pronechinus? sp. (1) Interambulacral plate of Permocidaris? timorensis (Wanner, 1941) from the Permian of Timor (RGM 835575). Specific locality unknown. Crenulate tubercle of this taxon is very similar to those of the indeterminate archaeocidarid in Figure 2.6, 2.7. (2) Interambulacral plate of holotype of Archaeocidaris manhattanensis (MGL 206289). Note plate dimensions, which are similar to those of Archaeocidaridae indet. in Figure 2.7-2.9. (3) Syntype of Archaeocidaris forbesiana (NMS G.1871.1.34); (4) First plate morphotype of Archaeocidaridae indet. (USNM 617188a); (5) interior view of same plate; note lack of denticulate margin indicating median location of plates. (6) Crenulate interambulacral plate of Archaeocidaridae indet. (USNM 617188b); (7) crenulate interambulacral plate of second plate morphotype of Archaeocidaridae indet. (USNM 617189); (8) adambulacral second interambulacral plate morphotype of Archaeocidaridae indet. (USNM 617189). Note plate dimensions, which are much higher than wide. (9) Interior side of the same; (10) spine of Archaeocidaridae indet. (USNM 617187a); (11) The same in cross section. Note triangular cross section. (12) Base and acetabulum of spine (USNM 617187b); (13) the same spine in plan view; (14) thin spine of Archaeocidaridae indet. (USNM 617187c); (15) ambulacral plate of Pronechinus? sp. with well-developed peripodial ring surrounding pore pairs (USNM 617193); (16) ambulacral plate of Pronechinus? sp. with peripodial ring and imperforate primary tubercle (USNM 617194); (17) same as 2.16 but in side view; (18) ambulacral plate lacking peripodial ring and with imperforate primary tubercle (USNM 617195); (19) ambulacral plate lacking well-defined peripodial ring and primary tubercle (USNM 617196); (20) interambulacral plate of Pronechinus? sp. with large imperforate primary tubercle (USNM 617197a); (21) nontuberculate interambulacral plate of Pronechinus? sp. (USNM 617197b). Scale bars $=2.5 \mathrm{~mm}$. 


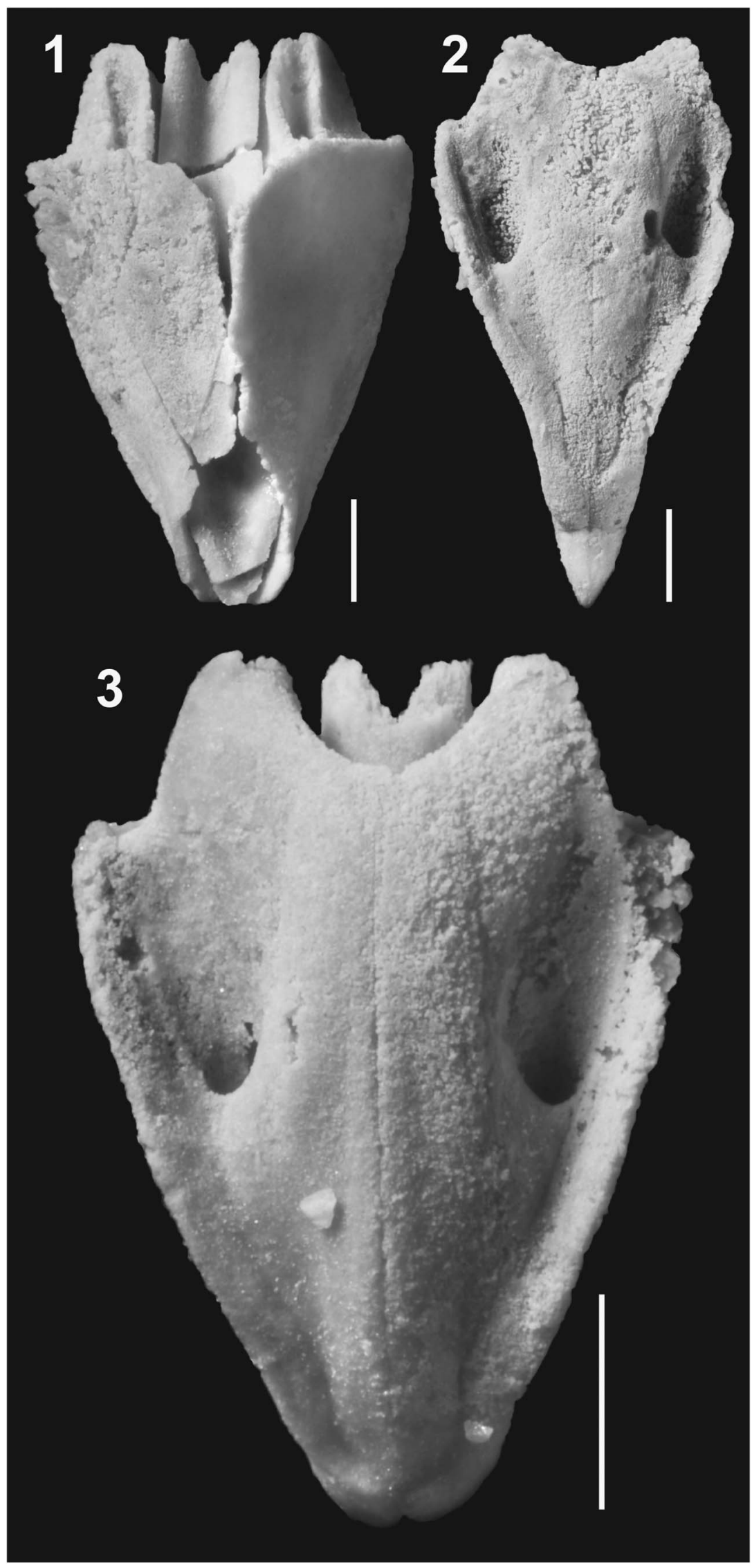

Figure 3. Pyramids of indeterminate echinoid. (1) Pyramid of indeterminate echinoid (USNM 617190a); (2) pyramid of indeterminate echinoid (USNM 617190b). Tooth comes to a single nonserrate point. (3) Pyramid of indeterminate echinoid (USNM 617190c). Scale bars $=2.5 \mathrm{~mm}$. 
those described as Population A in Hoare and Sturgeon (1976). They attribute these lanterns to either Archaeocidaris or Polytaxicidaris. The foramen magnum slopes at a gentler angle in the lanterns attributed to Archaeocidaris? jacksoni Spreng and Howe, 1963 and Archaeocidaris? remotus Spreng and Howe, 1963 than in the pyramids herein described. In addition, the indeterminate lanterns appear to have less-sloping foramen magna then those of the lanterns described by Kier (1958b) from the Wordian of west Texas. Proterocidarid lanterns are also not well enough known to confidently assign the herein described taxon to Pronechinus? sp. The lantern characteristics of particular clades of echinoids in the Paleozoic are not well known, as pointed out by Spreng and Howe (1963). This is in part because lanterns are often assigned to genera and species without the presence of any articulated test material and are often given the names of taxa that are associated with disarticulated plates and spines of preexisting genera. This results in inconsistency regarding the association of lanterns with particular genera and species, and thus the lantern characteristics attributable to higherlevel taxa are not well known. Because of this, the characteristics of the lanterns described herein preclude assignment to a particular taxonomic group, and thus they are left in open nomenclature.

The teeth associated with these lanterns are of interest primarily because they do not have a serrated point and thus are not like the teeth typically associated with archaeocidarids and proterocidarids. Archaeocidaris, Polytaxicidaris, and the proterocidarids Proterocidaris de Koninck, 1882 and Fournierechinus Jackson, 1929 display serrated teeth constructed of multiple rows of columns of primary and secondary plates. These are termed 'compound lamellar teeth' (Reich and Smith, 2009). That the teeth present herein do not display the serrated tip characteristic of compound lamellar teeth suggests that they are not compound lamellar in origin. The nature of echinoid tooth microstructure is best understood through scanning electron microscopy analyses; however, due to the silicified nature of the material described herein, we did not attempt to examine the microstructure of the teeth. That they do not appear to be compound lamellar, however, leaves a few hypotheses regarding the nature of the teeth. They could be from a taxon not present in the described fauna; however, this seems unlikely given the nature of the material and its preparation, which exposed the entire silicified fauna of the limestone blocks. Furthermore, these pyramids could belong to Archaeocidaridae indet. or Pronechinus? sp. The nonserrate morphology may indicate either a primitive (e.g., simple lamellar) or derived (e.g., cidaroid-type U-shaped) tooth. U-shaped teeth are known from the Permian of the Ford Formation associated with the cidaroid Eotiaris keyserlingi and had clearly evolved by the Permian (Smith and Hollingworth, 1990). The teeth present in this west Texas fauna do have the U-shaped cross section characteristic of cidaroid teeth; however, without microstructural analysis, their affinities remain unclear.

\section{Discussion}

The assemblage herein described is particularly diverse by Permian standards. That this assemblage is so diverse relative to other Permian echinoid occurrences is likely due to the interplay of a number of competing factors, including worker bias, paleoenvironmental setting, and taphonomy.

This is the first study to methodologically identify disarticulated echinoid ossicles to the taxonomic rank of family in the Permian, though the approach has been used with much success in older strata (e.g., Kutscher and Reich, 2004; Reich and Smith, 2009; Thompson and Denayer, 2016). It has been demonstrated that the examination and identification of disarticulated echinoid ossicles increases the number of taxa known from a given formation (e.g., Gordon and Donovan, 1992; Donovan, 2001; Kroh, 2007; Thompson and Denayer, 2016). In addition, it is expected that when disarticulated echinoid ossicles are used to evaluate diversity estimates, recorded species richness will be higher than when solely articulated specimens are used (Nebelsick, 1996). Therefore, it is possible that the diversity of the assemblage herein observed is higher than that of other localities in the Permian due to the failure of previous studies to account for disarticulated ossicles.

The silicified nature of fossils from the Permian of the Guadalupe Mountains also undoubtedly plays a role in the higher reported diversity. Because the examined specimens were silicified and later dissolved out of limestone blocks, a greater number of specimens were available for study. Silicified faunas also often yield higher diversity aragonitic mollusk faunas than those that are not silicified (Cherns and Wright, 2000, 2009; Wright et al., 2003); however, it is unknown whether the same would be true of the high-magnesium calcite echinoderm faunas. Regardless, if the specimens reported herein were not silicified, and therefore could not have been easily dissolved from their interring matrix, then only specimens on bedding planes would have been visible. To our knowledge, no other silicified Permian echinoid faunas from outside of west Texas have been acquired through dissolution of $\mathrm{CaCO}_{3}$ matrix. This technique has, however, yielded exceptional preservation and increased estimates of diversity and abundance in Pennsylvanian (Kier, 1965) and Triassic (Stanley, 1989; Smith, 1994 described in Stanley, 1994) faunas. It is probable that if other silicified Permian faunas are prepared through matrix dissolution techniques, they will yield comparably diverse faunas.

It is also possible that the assemblage herein described has a relatively high diversity because of the depositional environment from which it was collected. This assemblage preserves a transported reefal community (Babcock, 1977). Reefal communities have been shown to contain diverse regular echinoid assemblages in the Red Sea, and the sediments associated with these reefal environments also preserve disarticulated components of diverse regular echinoid assemblages (Nebelsick, 1996). A transported reefal community may also have preserved a mixed assemblage representing the wide range of microhabitats that echinoids inhabit on a reef. Although reefal environments are unlikely to preserve a full suite of articulated echinoid communities due to their high-energy setting (Nebelsick, 1996), as mentioned in the preceding, when disarticulated material is accounted for, a more diverse assemblage is likely to be preserved. Also of importance is the fact that this is not the first Permian reef to yield fossil echinoids. The Wuchiapingian Zechstein reefs of the Ford Formation from Northern England (Hollingworth and Pettigrew, 1988; Smith 
and Hollingworth, 1990) and the Zechstein Reefs of Thuringia, Germany (Reich, 2007 and references therein) are both known to contain the stem group cidaroid Eotiaris keyserlingi. It is thus possible that reefal environments in the late Paleozoic may have supported diverse echinoid communities and that the assemblage described here is so diverse simply because of the reefal nature of the sediments in which it was preserved. That two species of Eotiaris, E. guadalupensis and E. keyserlingi, are both reported exclusively from reefal environments may also indicate that early crown group echinoids evolved, or at least thrived, in these environments. These Permian reefal environments are also not the oldest such Paleozoic reefal settings to yield echinoid faunas. Although their framework differs from reefs of the Permian, Mississippian mud mounds from the Fort Payne Formation of Kentucky (Thompson and Ausich, 2016) and the Waulsortian mud mounds of Clitheroe, Lancashire (Hawkins, 1935; Donovan et al., 2003), and Waulsort, Belgium (Jackson, 1929), have also yielded diverse and abundant echinoid faunas and were likely favorable habitats for echinoids. It has also been recently proposed that Triassic echinoids may have had an affinity for reefal environments (Zonneveld et al., 2015) as much of the known Triassic echinoid fossil record is from reefal settings (e.g., Kier, 1977, 1984; Stanley, 1979, 1989; Smith, 1994; Zonneveld, 2001; Zonneveld et al., 2007). Many of these Triassic taxa are stem group cidaroids belonging to the Miocidaridae (e.g., Zonneveld et al., 2007) and the families Triadocidaridae and Paurocidaridae (e.g., Smith, 1994), which are likely to be descendants of miocidarids such as Eotiaris guadalupensis (Smith, 2007). Given the abundance of these stem cidaroids in reefal environments in the Permian and Triassic, it is possible that the early diversification of stem group cidaroids may have taken place in reefal environments; however, more data will be necessary to further test this hypothesis.

Co-occurrence of stem group and crown group echinoids.From a paleoecological standpoint, this fauna is important because it demonstrates a depositional environment in which archaeocidarids, proterocidarids, and miocidarids coexisted. Permian miocidarids have until now only been reported from assemblages where they are the only echinoid constituent (Kier, 1965; Reich, 2007) and that miocidarids are herein found from the same environments as archaeocidarids indicates that the most crownward stem group echinoids, the archaeocidarids, and the earliest crown group echinoids, the miocidarids, were occupying the same environments at the same time. This is particularly interesting given the survival of the miocidarids through the Permian-Triassic mass extinction (Smith and Hollingworth, 1990; Erwin, 1993, 1994), which appears to have been responsible for the extinction of the archaeocidarids. Miocidarids outside of localities in west Texas are only known from the two reefal localities described in the preceding. Archaeocidarids, however, were much more abundant and apparently more geographically widespread as they have been described from test or interambulacral plate material from localities in Texas (Kier, 1958b; Schneider, 2010; this paper), Australia (Etheridge, 1892; Webster and Jell, 1992), Kansas (Boos, 1929; Matthieu, 1949), Oklahoma (Boos, 1929), Pakistan (Waagen, 1885), Tunisia (Matthieu, 1949), Timor (Wanner, 1941), Argentina (Hlebzevitsch and Cortiñas, 2009),
Hungary (Mihály, 1980), and Bosnia (Kittl, 1904). This abundance of archaeocidarids, relative to miocidarids, makes their demise at the Permian-Triassic boundary interval even more interesting, and currently there exists no good mechanism to explain the differential survival of the miocidarids and archaeocidarids. Furthermore, there is no good understanding of the temporal distribution of Permian archaeocidarid abundance or diversity at the stage level or lower, which will be necessary to understand the dynamics of stem group echinoid richness and abundance leading up to the Permian-Triassic boundary. For example, the end-Guadelupian extinction event (Stanley and Yang, 1994), which was responsible for major extinctions in some clades (e.g., fusulinids; Stanley and Yang, 1994; Groves and Wang, 2013) and only slightly elevated extinction rates in others (Payne and Clapham, 2012; Clapham, 2015), may have played a role in extinction of the archaeocidarids; however, whether this is the case remains to be seen.

The acquisition of characters leading to crown group echinoids.-New fossil discoveries are key for establishing the sequence of character evolution associated with the transition from stem group to crown group taxa. As specimens with new morphologies are discovered, a clearer picture of the order of character changes leading from the stem group to the crown group becomes available, and the true synapomorphies defining the crown group become apparent (Donoghue, 2005). Basal crown group echinoids have previously been united by a number of synapomorphies, which distinguish them from members of the echinoid stem group. Among the most conspicuous of these synapomorphies are the reduction in coronal plating to two columns of interambulacral plates and two columns of ambulacral plates and the evolution of the perignathic girdle (for a complete list of crown group echinoid synapomorphies, see Kroh and Smith, 2010). In addition, although not demonstrably present in the most basal euechinoids (for which there is little fossil evidence), the earliest, and most basal, cidaroid taxa also display crenulate tubercles and a rigid interambulacral area at and below the ambitus (Kier, 1965; Smith and Hollingworth, 1990; Thompson et al., 2015b). Before this study, neither a perignathic girdle, an interambulacral area composed of two columns of plates, and crenulate tubercles, were known to be present in the most derived stem group echinoids, which belonged to the genus Archaeocidaris. It is very unlikely, however, that the acquisition of these three characters took place all at once as evolutionary transitions marked by large numbers of character acquisitions are often incremental (e.g., Donoghue and Purnell, 2005; Mackovicky and Zanno, 2011). Although it is well known that the origination of crown group echinoids took place in the late Paleozoic (Smith and Hollingworth, 1990; Smith et al., 2006; Nowak et al., 2013; Thompson et al., 2015b), the order of character state transitions associated with, and leading up to, the origination of the crown group is not well understood.

The new specimens of Archaeocidaridae indet. from west Texas appear to shed light on the order of some of the character changes associated with the morphological transition from stem group to crown group echinoids (Fig. 4). The interambulacral plates of this indeterminate archaeocidarid are composed of pentagonal and hexagonal forms (Fig. 2.4-2.9). On one interior 


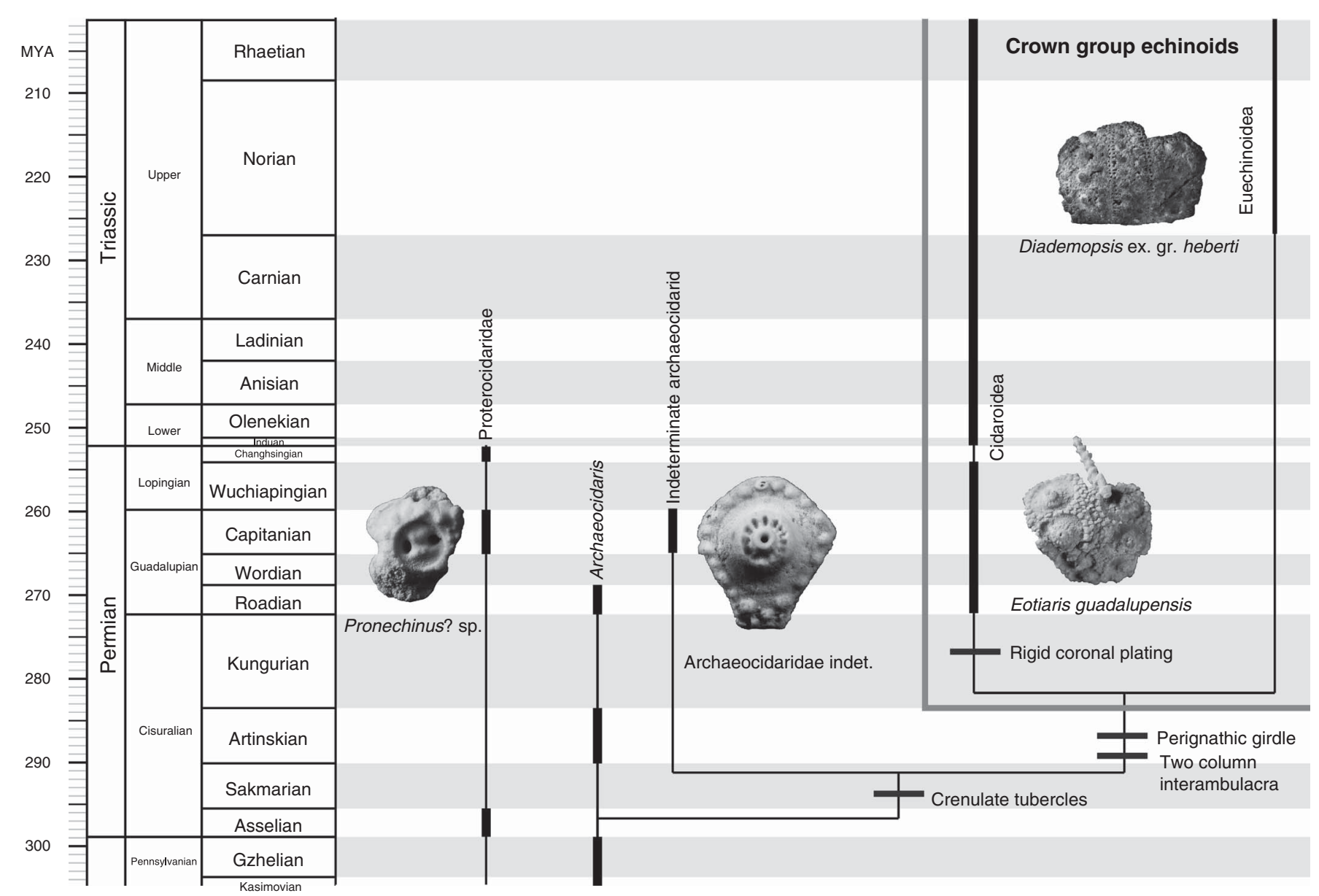

Figure 4. Simplified cartoon showing hypothesized order of select character acquisitions along the branch from stem group to crown group echinoids and stratigraphic distribution of taxa described herein and other named proterocidarid, archaeocidarid, and miocidarid taxa from the Permian (excluding Eotiaris connorsi [Kier, 1965], whose position within the Miocidaridae is currently being tested [unpublished data, Thompson, 2016]). The oldest demonstrable euechinoid is also shown for comparison. The lineage leading to archaeocidarids and miocidarids likely diverged from that giving rise to the proterocidarids in the Devonian or earlier (Smith, 1984) and is not figured. Only Archaeocidaris species known from relatively articulated test material are included, and branching events do not reflect time scaling. Archaeocidaris is a stem group echinoid, while Eotiaris guadalupensis Thompson n. sp. and Diademopsis ex. gr. heberti (Agassiz and Desor, 1846) are the oldest fossil cidaroid and euechinoids, respectively, and are among the oldest members of the crown group. The crenulate tubercles of Archaeocidaridae indet. indicate that crenulate tubercles likely evolved in the echinoid stem group before the reduction in interambulacral columns from four to two, and before the acquisition of a perignathic girdle. Consequently, crenulate tubercles appear to have preceded the acquisition of rigid coronal plating in cidaroids. For full suite of characters defining the echinoid crown group, see Kroh and Smith (2010). Occurrences of Archaeocidaris are from Etheridge (1892) and Boos (1929). Proterocidarid occurrences are from Kier (1965), König (1982), and this study. The indeterminate archaeocidarid is described herein. Crown group echinoids within gray box. Figure plotted in STRAP (Bell and Lloyd, 2015).

edge, the pentagonal plates bear a distinct denticulate margin, where the plates of the interambulacral plate imbricated over the adjacent ambulacral plates (Fig. 2.9). Furthermore, the hexagonal interambulacral plates do not bear this denticulate margin (Fig. 2.5), therefore assuredly not beveling over ambulacral plates and therefore belonging to median interambulacral columns. This indicates that the test of this indeterminate archaeocidarid was composed of interambulacral areas with more than two columns of plates, as was the case for Archaeocidaris, with its four columns of interambulacral plates. In addition to having multiple columns of interambulacral plates, the interambulacral plates of Archaeocidaridae indet. bear crenulate tubercles (Fig. 2.6, 2.7). In regular echinoids, crenulate tubercles interlock with crenulations on the acetabulum of the spine. In Archaeocidaridae indet., these crenulate tubercles appear to have acted as a restricted-pivot tubercle sensu Smith (1980b), which would have offered each tubercle a lesser range of motion but resulted in more sturdy support for the spines. Restricted-pivot tubercles are often associated with extant taxa that use large primary spines for defense against predators (Smith, 1980b), and this may have been the utility of crenulate tubercles in Archaeocidaridae indet. Regardless of their purpose, their presence in the indeterminate archaeocidarid described herein indicates that crenulate tubercles, a character previously only definitively present in the fossil record from crown group echinoids such as Eotiaris, were in fact present in members of the stem group, the archaeocidarids. The most basal cidaroids (family Miocidaridae) and some of the most basal euechinoids of the Echinothurioida display crenulate tubercles (Kroh and Smith, 2010; Thompson et al., 2015b), and as such it is not entirely surprising that this character appears to have preceded the euechinoid-cidaroid divergence. The evolution of crenulate tubercles also appears to have preceded the evolution of the perignathic girdle and the reduction in coronal plating 
from four columns of interambulacral plates to two (Fig. 4). Furthermore, this character seems to have been widespread, as crenulate tubercles are known in Permian archaeocidarids from Timor (Wanner, 1841, fig. 2.1), Pakistan (Waagen, 1985), and Hungary (Mihály, 1980). The discovery of archaeocidarids with crenulate tubercles allows for a better understanding of the probable last common ancestor of the euechinoids and cidaroids. That the innovation of crenulate tubercles likely preceded the evolution of a perignathic girdle and the reduction of interambulacral plating to two columns indicates that the evolution of crenulate tubercles probably preceded the last common ancestor of euechinoids and cidaroids, and thus this last common ancestor likely bore crenulate tubercles. It is, of course, possible that the Archaeocidaridae indet. described herein is a separate lineage of archaeocidarids, which convergently evolved crenulate tubercles that are not homologous to those of the miocidarids. The ideal way to test this hypothesis would be through phylogenetic analyses. The material described herein, however, is too incomplete to incorporate into a quantitative phylogenetic analysis as the specimens described herein are composed solely of disarticulated material, with numerous characters that would need to be coded as unknown. Furthermore, these unknown data are not random, given that the taxon's interambulacral plates and spines are the only morphological features that are preserved. Nonrandom preservation, and subsequent nonrandom missing characters, can introduce systematic bias into the topological placement of taxa in cladograms (Sansom and Wills, 2013). This can be a particularly serious problem with respect to determining the phylogenetic placement of taxa near the crown group-stem group transition, as crown group taxa with many missing characters can appear to be members of the stem group (e.g., Sansom et al., 2010). That the indeterminate archaeocidarid described herein had more than two columns of interambulacral plates indicates it is likely a member of the stem group. We hope, however, to test the hypotheses of character evolution put forth herein in a rigorous phylogenetic context with the discovery of more complete specimens in the future.

\section{Conclusions}

The Permian echinoid fauna described here expands upon previously known echinoid diversity in the Permian and sheds light on the Paleozoic divergence of crown group echinoids. This is one of the most diverse faunas of echinoids known from the Permian and indicates that a number of major families, the Archaeocidaridae, Proterocidaridae, and the Miocidaridae, coexisted in reefal environments adjacent to the Delaware Basin. The presence of Eotiaris guadalupensis in reefal environments, similar to those inhabited by the European Eotiaris keyserlingi, may indicate that stem group cidaroids originated and preferentially thrived in these reefal environments. Furthermore, the presence of crenulate tubercles on the indeterminate archaeocidarid indicates that crenulate tubercles evolved in archaeocidarids, likely before the reduction in interambulacral columns from four to two and the evolution of the first perignathic girdle. Crenulate tubercles may thus be plesiomorphic with respect to the echinoid crown group.

\section{Acknowledgments}

This work was funded by National Science Foundation Grant IOS1240626. The authors thank S. Wing, M. Florence, D. Levin, J. Strotman, and K. Hollis at the USNM; A. Molineux at the Texas Memorial Museum, Austin, Texas; J. Cuvelier at the Université Lille; Y. Candela at the National Museums Scotland; and T. Ewin at the Natural History Museum, London, for providing access to specimens and specimen numbers. Furthermore, N. den Ouden provided access to specimens at Naturalis Biodiversity Center, Leiden, and S. Donovan provided the photograph in Figure 2.1. S. Zamora was instrumental in arranging the plates, and his suggestion of a black background improved the clarity of the photos. JRT acknowledges a student grant from the Palaeontological Association, which covered costs for the Progress in Echinoderm Palaeontology meeting in Zaragoza, Spain, from which this volume has been produced. Finally, we thank A. Kroh and L. Zachos, our reviewers, for their instructive comments, which helped to refine the manuscript.

\section{References}

Agassiz, L., and Desor, E., 1846, catalogue raisonné des families, des generes et des espéces de la classe des Echinodermes: Annales des Sciences Naturelles, Troisiéme Série, Zoologie, v. 6, p. 305-374.

Babcock, L.C., 1977, Life in the Delaware Basin: The paleoecology of the Lamar Limestone, in Upper Guadalupian Facies, Permian Reef Complex, Guadalupe Mountains, New Mexico and West Texas: Permian Basin Section SEPM Publication 79-18, p. 357-389.

Bather, F.A., 1909, Eocidaris and some species referred to it: Annals and Magazine of Natural History Decade 8, v. 33, p. 43-66.

Bell, M.A., and Lloyd, G.T., 2015, strap: An R package for plotting phylogenies against stratigraphy and assessing their stratigraphic congruence: Palaeontology, v. 58, p. 379-389.

Behnken, F.H., 1975, Leonardian and Guadalupian (Permian) conodont biostratigraphy in western and southwestern United States: Journal of Paleontology, v. 49, p. 284-315.

Boos, M.F., 1929, Stratigraphy and fauna of the Luta Limestone (Permian) of Oklahoma and Kansas: Journal of Paleontology, v. 3, p. 241-253. Butts, S.H., and Briggs, D.E.G., 2011, Silicification through time, in Allison, P.A., and Bottjer, D.J., eds., Taphonomy: Process and Bias Through Time: Dordrecht, Springer, p. 411-434.

Cherns, L., and Wright, V.P., 2000, Missing molluscs as evidence of large-scale, early skeletal aragonite dissolution in a Silurian sea: Geology, v. 28, p. 791-794.

Cherns, L., and Wright, V.P., 2009, Quantifying the impacts of early diagenetic aragonite dissolution on the fossil record: Palaios, v. 24, p. 756-771.

Clapham, M.E., 2015, Ecological consequences of the Guadalupian extinction and its role in the brachiopod-mollusk transition: Paleobiology, v. 42, p. 266-279.

Cooper, A.G., and Grant, R.E., 1972, Permian Brachiopods of West Texas, part I: Smithsonian Contributions to Paleobiology, v. 14, p. 1-231.

de Beer, M., 1990, Distribution patterns of regular sea urchins (Echinodermata: Echinoidea) across the Spermonde Shelf, SW Sulawesi (Indonesia), in de Ridder, C., Dubois, P., and Lahaye, C., eds., Echinoderm Research. Proceedings of the Second European Conference on Echinoderms, Brussels, Belgium, 18-21 September 1989: Rotterdam, A. A. Balkema, p. $165-169$.

de Koninck, L., 1863, Description of some fossils from India, discovered by Dr. A. Fleming, of Edinburgh: Quarterly Journal of the Geological Society of London, v. 19, p. 1-19.

de Koninck, L., 1882, Notice sur un échinooïde gigantesque du calcaire carbonifére de Belgique: Association francaise pour l'Avancement des Sciences, Compte Rendu de la 10e Session, Alger, p. 514-515.

Desor, E., 1855-1858, Synopsis des échinides fossiles: Paris, Reinwald, 490 p. Döderlein, L., 1887, Die Japanischen Seeigel. I Theil. Familie Cidaridae und Salenidae: Stuttgart, E. Schweizerbartsche Verlagshandlung, 60 p.

Donoghue, P.C.J., 2005, Saving the stem group-a contradiction in terms? Paleobiology, v. 31, p. 553-558. 
Donoghue, P.C.J., and Purnell, M.A., 2005, Genome duplication, extinction and vertebrate evolution: TRENDS in Ecology and Evolution, v. 20, p. 314-319.

Donovan, S.K., 2001, Evolution of Caribbean echinoderms during the Cenozoic: Moving towards a complete picture using all of the fossils: Palaeogeography, Palaeoclimatology, Palaeoecology, v. 166, p. 177-192.

Donovan, S.K., Lewis, D.N., and Crabb, P., 2003, Lower Carboniferous echinoderms of North-West England: Palaeontological Association Fold-Out Fossils, v. 1.

Durham, J.W., and Melville, R.V., 1957, A classification of echinoids: Journal of Paleontology, v. 31, p. 242-272.

Erwin, D. H., 1993, The Great Paleozoic Crisis: Life and Death in the Permian: New York, Columbia University Press, 327 p.

Erwin, D.H., 1994, The Permo-Triassic extinction: Nature, v. 367, p. 231-236.

Etheridge, R., 1892, A monograph of the Permo-Carboniferous invertebrata of New South Wales Part II.-Echinodermata, Annelida, and Crustacea: Memoirs of the Geological Survey of New South Wales: Paleontology, v. 5, p. 1-132.

Gagnon, J., and Gilkinson, K.D., 1994, Discrimination and distribution of the sea urchins Strongylocentrotus droebachiensis (O.F. Müller) and S. pallidus (G. O. Sars) in the Northwest Atlantic: Sarsia, v. 79, p. 1-11.

Geinitz, H.B., 1848, Die Versteinerungen des deutschen Zechsteingebirges und Rothliegenden oder des Permischen Systems in Sachsen: Dresden and Leipzig, Arnoldische Buchhandlung, $26 \mathrm{p}$.

Gordon, C.M., and Donovan, S.K., 1992, Disarticulated echinoid ossicles in paleoecology and taphonomy: The last interglacial Falmouth Formation of Jamaica: Palaios, v. 7, p. 157-166.

Gortani, M., 1905, Fossili carboniferi del M. Pizzul e de piano di Lanza nelle Alpi Carniche: Bolletino Società Geologica Italiana, v. 24, p. 521-597.

Groves, J.R., and Wang, Y., 2013, Timing and size selectivity of the Guadalupian (middle Permian) Fusulinoidean extinction: Journal of Paleontology, v. 87 , p. $183-196$

Hall, J., 1858, Report on the Geological Survey of the State of Iowa: Embracing the results of investigations made during portions of the years, 1855, 56 \& 57: Geological Survey of Iowa, 724 p.

Hawkins, H.L., 1935, Two genera of Carboniferous Echinoidea (Lepidocidaris and Hyattechinus) new to Britain: Quarterly Journal of the Geological Society, v. 91, p. 239-250.

Henderson, C.M., Davyvov, V.I., and Wardlaw, B.R., 2012, The Permian Period, in Gradstein, F., Ogg, J., Schmitz, M., and Ogg, G., eds., The Geologic Timescale 2012: Amsterdam, Elsevier, p. 653-680.

Hlebszevitsch, J.C., and Cortiñas, J.S., 2009, El Registro más antiguo de echinoidea en Argentina y el contacto Pérmico-Jurásico inferior en la region del Río Geona, Chubut: Revista de la Associación Geológica Argentina, v. 65 , p. $479-486$

Hoare, R.D., and Sturgeon, M.T., 1976, Echinoid remains from the Pennsylvanian Vanport Limestone (Allegheny Group), Ohio: Journal of Paleontology, v. 50, p. 13-24.

Hollingworth, N., and Pettigrew, T., 1988, Zechstein Reef Fossils and Their Palaeoecology: London, The Palaeontological Association, 75 p.

Hopkins, M.J., and Smith, A.B., 2015, Dynamic evolutionary change in postPalaeozoic echinoids and the importance of scale when interpreting changes in rates of evolution: Proceedings of the National Academy of Sciences of the United States of America, v. 112, p. 3758-3763.

Jackson, R.T., 1912, Phylogeny of the Echini, with a revision of Palaeozoic species: Memoirs of the Boston Society of Natural History, v. 7, p. 1-491.

Jackson, R.T., 1929, Palaeozoic echini of Belgium: Mémoires du Musée Royal D'Histoire Naturelle de Belgique, v. 38, p. 1-96.

Kier, P.M., 1958a, New American Paleozoic echinoids: Smithsonian Miscellaneous Collections, , v. 135, p. 1-26.

Kier, P.M., 1958b, Permian echinoids from West Texas: Journal of Paleontology, v. 32, p. 889-892.

Kier, P.M., 1965, Evolutionary trends in Paleozoic echinoids: Journal of Paleontology, v. 39, p. 436-465.

Kier, P.M., 1977, Triassic echinoids: Smithsonian Contributions to Paleobiology, v. 30, p. 1-86.

Kier, P.M., 1984, Echinoids from the Triassic (St. Cassian) of Italy, their lantern supports, and a revised phylogeny of Triassic echinoids: Smithsonian Contributions to Paleobiology, v. 56, p. 1-41

Kier, P.M., and Grant, R.E., 1965, Echinoid distribution and habits, Key Largo Coral Reef Preserve, Florida: Smithsonian Miscellaneous Collections, v. 149, p. $1-68$.

Kittl, E., 1904, Geologie der Umgebung von Sarajevo: Jahrbuch der k. k. geologischen Reichsanstalt, v. 53, p. 516-748.

König, V.H., 1982, Unterpermische Seeigel aus Kreta (Griechenland): Neues Jahrbuch für Geologie und Palaontologie. Monatshefte, v. 3, p. 167-175.

Kozur, H., 1992, Dzhulfian and early Changxingian (late Permian) Tethyan conodonts from the Glass Mountains, West Texas: Neues Jahrbuch für Geologie und Paläontologie Abhandlungen, v. 187, p. 99-114.
Kroh, A., 2007, Climate changes in the early to middle Miocene of the Central Paratethys and the origin of its echinoderm fauna: Palaeogeography, Palaeoclimatology, Palaeoecology, v. 253, p. 169-207.

Kroh, A., and Smith, A.B., 2010, The phylogeny and classification of postPalaeozoic echinoids: Journal of Systematic Palaeontology, v. 8, p. $147-212$.

Kutscher, M., and Reich, M., 2004, Archaeocidarid and bothriocidarid Echinozoa from the Silurian of Gotland, Sweden, in Heinzeller T., and Nebelsick, J.H., eds., Echinoderms: München: Proceedings of the 11th International Echinoderm Conference, 6-10 October 2003, Munich Germany: London, Taylor and Francis Group, p. 457-458.

Lambert, J., 1899, Échinodermes: Revue critique de Paleozoologie, v. 3, p. $82-84$

Lambert, J., 1900, Étude sur quelques échinides de l'infra-Lias et du Lias: Bulletin de la Société des Sciences Historiques et Naturelles de l'Yonne, v. 53 , p. $3-57$.

Lambert, L.L., 2006, Taxonomic update for Reef Trail conodonts illustrated in Wilde et al. 1999, in Hinterlong, G., ed., Basinal Facies of the Uppermost Guadalupian: Applicability to Exploration and Development Projects; Field Trip Guidebook Permian Basin Section, SEPM Publication 2006-46: Midland, Society for Sedimentary Geology. Permian Basin Section, p. $78-85$.

Lambert, L.L., Wardlaw, B.R., Nestell, M.K., and Nestell, G.P., 2002, Latest Guadalupian (middle Permian) conodonts and foraminifers from West Texas: Micropaleontology, v. 48, p. 343-364.

Lambert, L.L., Bell, G.L., Fronimos, J.A., Wardlaw, B.R., and Yisa, M.O., 2010, Conodont biostratigraphy of a more complete Reef Trail Member section near the type section, latest Guadalupian Series type region: Micropaleontology, v. 56, p. 233-256.

Leske, N.G., 1778, Iacobi Theodori Klein Naturalis disposito Echinodermatum, Edita et aucta a N.G. Leske: Leipzig, G.E. Beer, 278 p.

Leupke, G., 1976, Archaeocidaris spines from the Permian Scherrer Formation, Southeastern Arizona: Journal of the Arizona Academy of Science, v. 11, p. 87-88.

Lewis, D.N., and Donovan, S.K., 2007, A standardized method of describing fossils, using Echinoidea as an example: Scripta Geologica, v. 134, p. $109-118$.

Lewis, D.N., and Ensom, P.C., 1982, Archaeocidaris whatleyensis sp. nov. (Echinoidea) from the Carboniferous Limestone of Somerset, and notes on echinoid phylogeny: Bulletin of the British Museum of Natural History (Geology), v. 36, p. 77-104.

Linse, K., Walker, L.J., and Barnes, D.K.A., 2008, Biodiversity of echinoids and their epibionts around the Scotia Arc, Antarctica: Antarctic Science, v. 20, p. $227-244$.

Makovicky, P.J., and Zanno, L.E., 2011, Theropod diversity and the refinement of avian characteristics, in Dyke, G., and Kaiser, G., eds., Living Dinosaurs: The Evolutionary History of Modern Birds: Oxford, John Wiley \& Sons, p. 9-29.

Matthieu, G., 1949, Contribution a l'étude des monts troglodytes dans l'extreme Sud-Tunisien: Geologie regionale des environs de Matmata Medenine et Foum-Tatahouine: Tunis, Imprimerie S.A.P.I., 78 p.

M'Coy, F., 1844, A Synopsis of the Characters of the Carboniferous Limestone Fossils of Ireland: Dublin, University Press, $207 \mathrm{p}$

Mihály, S., 1980, Echinoidea maradványok a Bükk hegység felsöpermjéböl: A Magyar Állami Földtani Intézet Évi Jelentése, v. 1978, p. 399-412.

Nebelsick, J.H., 1996, Biodiversity of shallow-water Red Sea Echinoids: Implications for the fossil record: Journal of the Marine Biological Association of the United Kingdom, v. 76, p. 185-194.

Nowak, M.D., Smith, A.B., Simpson, C., and Zwickl, D.J., 2013, A simple method for estimating informative node age priors for the fossil calibration of molecular divergence time analyses: PLoS ONE, v. 8, p. $1-13$.

Payne, J.L., and Clapham, M.E., 2012, End-Permian mass extinction in the oceans: An ancient analog to the twenty-first century: Annual Review of Earth and Planetary Sciences, v. 40, p. 89-111.

Pomel, A., 1883, Classification méthodique et Genera des Échinides vivantes et fossiles. Thèses présentées à la Faculté des Sciences de Paris pour obtenir le Grade de Docteur és Sciences Naturelles 503: Algiers, Adolphe Jourdan, $131 \mathrm{p}$.

Prosser, C.S., 1895, The classification of the upper Paleozoic rocks of Central Kansas: The Journal of Geology, v. 3, p. 764-800.

Reich, M., 2007, Linguaserra spandeli sp. nov. (Echinodermata: Ophiocistioidea) from the late Permian (Zechstein) of Thuringia, Germany: Annales de Paléontologie, v. 93, p. 317-330.

Reich, M., and Smith, A.B., 2009, Origins and biomechanical evolution of teeth in echinoids and their relatives: Palaeontology, v. 52, p. 1149-1168.

Sansom, R.S., and Wills, M.A., 2013, Fossilization causes organisms to appear erroneously primitive by distorting evolutionary trees: Scientific Reports, v. 3 , no. 2545 . 
Sansom, R.S., Gabbott, S.E., and Purnell, M.A., 2010, Non-random decay of chordate characters causes bias in fossil interpretation: Nature, v. 463, p. 797-800.

Schneider, C.L., 2010, Epibionts on late Carboniferous through early Permian echinoid spines from Texas, USA, in Harris, L.G., Böttger, S.A., Walker C.W., and Lesser, M.P., eds., Echinoderms: Durham: Proceedings of the 12th International Echinoderm Conference, 7-11 August 2006, Durham, New Hampshire, U.S.A.: Durham, CRC Press, p. 71-76.

Schneider, C.L., Sprinkle, J., and Ryder, D., 2005, Pennsylvanian (late Carboniferous) echinoids from the Winchell Formation, North-Central Texas, USA Journal of Paleontology, v. 79, p. 745-762.

Shumard, B.F., and Swallow, G.C., 1858, Descriptions of new fossils from the coal measures of Missouri and Kansas: Transactions of the Academy of Science of St. Louis, v. 1, p. 198-227.

Simpson, R.D., 1976, Systematic paleontology and paleoenvironmental analysis of the upper Permian Hueco Formation, Robledo and Dona Ana Mountains, Dona Ana County, New Mexico [Master Thesis]: El Paso, University of Texas, $256 \mathrm{p}$

Smith, A.B., 1980a, Stereom microstructure of the echinoid test: Special Papers in Palaeontology, v. 25, p. 1-85.

Smith, A.B., 1980b, The structure and arrangement of echinoid tubercles Philosophical Transactions of the Royal Society of London. Series B Biological Sciences, v. 289, 1-54.

Smith, A.B., 1984, Echinoid Palaeobiology: London, George Allen and Unwin, $190 \mathrm{p}$.

Smith, A.B., 1994, Triassic echinoids from Peru: Palaeontographica Abteilung A, v. 233, p. 177-202.

Smith, A.B., 2007, Intrinsic versus extrinsic biases in the fossil record: Contrasting the fossil record of echinoids in the Triassic and Early Jurassic using sampling data, phylogenetic analysis, and molecular clocks: Paleobiology, v. 33 , p. $310-323$.

Smith, A.B., and Hollingworth, N.T.J., 1990, Tooth structure and phylogeny of the upper Permian echinoid Miocidaris keyserlingi: Proceedings of the Yorkshire Geological and Polytechnic Society, v. 48, p. 47-60.

Smith, A.B., and Kroh, A., 2011, The Echinoid Directory: http://www.nhm.ac. uk/research-curation/projects/echinoid-directory (accessed July 31, 2015).

Smith, A.B., and Savill, J.J., 2001, Bromidechinus, a new Ordovician echinozoan (Echinodermata), and its bearing on the early history of echinoids Earth and Environmental Science Transactions of the Royal Society of Edinburgh, v. 92, p. 137-147.

Smith, A.B., Pisani, D., Mackenzie-Dodds, J.A., Stockley, B., Webster, B.L., and Littlewood, T.J., 2006, Testing the molecular clock: Molecular and paleontological estimates of divergence times in the echinoidea (Echinodermata): Molecular Biology and Evolution, v. 23, p. 1832-1851.

Spreng, A.C., and Howe, W.B., 1963, Echinoid jaws from the Mississippian and Pennsylvanian of Missouri: Journal of Paleontology, v. 37, p. 931-938.

Stanley, D.G., 1979, Paleoecology, structure, and distribution of Triassic coral buildups in western North America: The University of Kansas Paleontological Contributions, v. 65 , p. $1-58$

Stanley, G.D., 1989, An Upper Triassic reefal limestone, southern Vancouver Island, B.C.: Canadian Society of Petroleum Geologists, Memoir, v. 13, p. 766-776.

Stanley, G.D., 1994, Upper Triassic corals from Peru: Palaeontographica Abteilung A, v. 233, p. 75-98.

Stanley, S.M., and Yang, X., 1994, A double mass extinction at the end of the Paleozoic era: Science, v. 226, p. 1340-1344.
Thompson, J.R., and Ausich, W.I., 2016, Facies distribution and taphonomy of echinoids from the Fort Payne Formation (late Osagean, early Viséan, Mississippian) of Kentucky: Journal of Paleontology, v. 90, p. 239-249.

Thompson, J.R., and Denayer, J., 2016, Revision of echinoids from the Tournaisian (Mississippian) of Belgium and the importance of disarticulated material in assessing palaeodiversity: Geological Journal, doi: 10.1002/ gj.2783 (in online early view).

Thompson, J.R., Crittenden, J., Schneider, C.L., and Bottjer, D.J., 2015a, Lowe Pennsylvanian (Bashkirian) echinoids from the Marble Falls Formation, San Saba, Texas, USA: Neues Jarbuch für Geologie und Paläntologie, v. 276 , p. $79-89$.

Thompson, J.R., Petsios, E., Davidson, E.H., Erkenbrack, E.M., Gao, F., and Bottjer, D.J., 2015b, Reorganization of sea urchin gene regulatory networks at least 268 million years ago as revealed by oldest fossil cidaroid echinoid: Scientific Reports, v. 5, no. 15541

Twitchett, R.J., and Oji, T.O., 2005, Early Triassic recovery of echinoderms Comptes Rendus Palevol, v. 4, p. 531-542.

Vadet, A., 1991, Révision des Cidaris du Lias et du Dogger Européens: Mémoires de la Société Académique du Boulonnais, v. 10, p. 1-175.

von Buch, L., 1840, Beiträge zur Bestimmung der Gerbirgsformationen in Russland: Archiv für Mineralogie, Geognosie, Bergbau und Hüttenkunde, v. 15 , p. $1-128$.

Waagen, W.H., 1885, Productus limestone fossils, Part V: Salt Range Fossils: Palaeontologia Indica, Series 13, v. 1, p. 771-834.

Wanner, J., 1941, Neue Beiträge sur Kenntnis der permischen Echinodermen von Timor, XV. Echinoidea: Palaeontographica Supplement, v. 4, p. 297-314.

Wardlaw, B.R., 2008, Paleontologic database for the Guadalupe Peak 1:100,000 Quadrangle: A prototype for the National Paleontologic Database, Paleodata: U.S. Geological Survey Open-File Report 2008-1141, p. $1-99$.

Wardlaw, B.R., and Mei, S.L., 1998, A discussion of the early reported species of Clarkina (Permian Conodonta) and the possible origin of the genus, in Jin, Y.G., Wardlaw, B.R., and Wang, Y., eds. Permian Stratigraphy, Environments and Resources, Volume 2: Stratigraphy and Environments: Palaeoworld, v. 9, p. 33-52.

Webster, G.D., and Jell, P.A., 1992, Permian echinoderms from western Australia: Memoirs of the Queensland Museum, v. 32, p. 311-373.

Wright, V.P., Cherns, L., and Hodges, P., 2003, Missing molluscs: Field testing taphonomic loss in the Mesozoic through early large-scale aragonite dissolution: Geology, v. 31, p. 211-214.

Zonneveld, J.P., 2001, Middle Triassic biostromes from the Liard Formation, British Columbia, Canada: Oldest examples from the Mesozoic of NW Pangea: Sedimentary Geology, v. 145, p. 317-341.

Zonneveld, J.P., Henderson, C.M., Stanley, G.D., Orchard, M.J, and Gingras, M.K 2007, Oldest scleractinian coral reefs on the North American craton: Upper Triassic (Carnian), northeastern British Columbia, Canada: Palaeogeography, Palaeoclimatology, Palaeoecology, v. 243, p. 421-450.

Zonneveld, J.P., Furlong, C.M., and Sanders, S.C., 2015, Triassic echinoids (Echinodermata) from the Aksala Formation, North Lake Laberge, Yukon Territory, Canada: Papers in Palaeontology, v. 2, p. 1-14.

Accepted 29 November 2016 